\title{
Case Study: Exploring Learners' Emotional States in Practicing the 5R's Self Reflective Strategies on Their Reading Activities
}

\author{
Diah Astuty \\ Universitas Islam Lamongan \\ e-mail : diahastuty1412@gmail.com \\ Abdullah Farih \\ Universitas Islam Lamongan \\ e-mail : abdullahfarih@unisla.ac.id
}

\section{Article History}

Received: 18 January 2021

Reviewed: 11 February 2021

Accepted: 27 March 2021

Published: 27 April 2021

\section{Highlights}

Most students who accomplished learning logs and applied the 5R's self reflective strategies concerned of their triggered motivation to solve their learning problems in order to comprehend the provided L2 reading texts.

\begin{abstract}
This study presented the exploration on learners' emotional states while they're practicing the $5 \mathrm{R}$ 's self reflective strategies. The $5 \mathrm{Rs}$ consists of reporting stages, responding stages, relating stages, reasoning stages and reconstructing stages. Participants of this study were 10 students of a local university at East Java Province. The method of this study was institutional case study. The data in this study were participants' learning logs, questionnaires and online open ended interview results which conducted via zoom and Google meeting. The final result of interview was reported that most students who accomplished learning logs and applied the 5R's self reflective strategies concerned of their triggered motivation to solve their learning problems in order to comprehend the provided L2 reading texts.
\end{abstract}

Keywords: emotional states, 5Rs, self reflective strategies, case study

\section{Introduction}

Self reflection in learning is defined as the ways in which one reflects to what she/he has learned. The activities of self reflection in learning occur within learning periods; its process would require learners to analyze precious incidences in their learning activities. Following Heyler's thought on self reflection (2015:17), she exemplifies that reflective practices need to bring together the emotional practices with the logical practices from learners. The practices encourage 
learners to think on their learning experiences with the purpose of determining their learning behaviors, values and knowledge that learners have gained.

Meanwhile, teaching reading L2 texts to EFL learners have delivered some problematic situation to EFL teachers. Specifically, given reading materials for TOEFL teaching purpose can be categorized as intensive reading teaching in which EFL learners' reading comprehension must be gained. Reading comprehension can be acquired only in the learning situation wherein EFL learners can be active reader (Duke, 2010). There are supporting terms to encourage EFL learners becoming active reader for instance independent reading strategies choice, story structure and informational text structure. The use of self reflective strategies is considered going hand to hand with Duke's principle. Since self reflective strategies encourage EFL learners to become active readers by applying independent reading strategies through doing reflection on what learners have read.

Preliminary observation showed that the EFL teachers had to give more immense portion for drilling exercises in teaching L2 reading texts. Most of the EFL teachers assumed that drilling strategies with burden assignments for their students to accomplish could assist the students comprehended some provided L2 texts. Meanwhile, informal interview conducts to the EFL students informed that the implementation of drilling strategies made them becoming distressed of burden of exercises to carry out. Some students reported that their learning motivation on reading L2 texts diminished as the results. Students' learning motivation was one of indispensable factors to sustain reading comprehension from the students (Rowe, 2013). In associate with preliminary observation and interview results, the study reflected that the properly teaching learning strategies would be required. Thus, the research question for this study was to explore how the EFL students responded to the implementation of the 5R's self reflective strategies in learning $\mathrm{L} 2$ reading texts.

Adopting Kolb's learning styles (2013), there are three purposes to conduct self reflection in learning process that it involves meta cognitive knowledge. The purposes are 1) experience that individuals gain during their learning process, 2) the task completion of individual learners and 3) understanding about learning strategies to improve individual learners' learning. At this point, focusing on reflection practices that are evaluated alongside with meta-cognitive model can enhance a cycle of learning practice which involves expert models, feedback and scaffolding assistance to gain the learning goals.

$5 R$ 's self reflective strategies consist of five stages in making reflection to what learners have learned. The stages include reporting stages, responding stages, relating stages, reasoning stages and reconstructing stages. Regarding to Bain's concept (2002) about the 5R's self reflection, each stage of the 5 Rs reveals some purposes in learning and making reflection. For teaching intensive reading objectives, the $5 \mathrm{Rs}$ would be broken down into instructions for learners after they read some given $\mathrm{L} 2$ reading texts. 
Implementation of self reflective strategies refer to Bain's thoughts on the 5Rs steps of self reflective practices in learning L2 reading texts. Some selected L2 reading texts are provided for learners to learn that range from text types of academic texts and descriptive texts. Following to Bain (2002), the 5Rs can be range from reporting step, responding step, relating step, reasoning step and reconstructing step. Having manifested those 5Rs into self-reflective practices, consequently some learning practices are required. The required learning practices vary at assessing some provided L2 reading texts' content, applying some reading techniques to scaffold learners' comprehension, making inferences, exploring some stated inferences and interpreting L2 reading texts' content.

At advance, this study explores the emotional states of EFL learners while they were practicing self reflective strategies that entitled the 5Rs. Managing the use of learning logs that were distributed to EFL learners, the study is going to present the exploration of EFL learners' learning logs in exposing the learners' mental states while they learned reading by implementing the 5Rs.

In addition to Hascher (2009:14), she presents some ideas on description of emotional states. Emotion is affective response that can be clarified and ascribed to an occurrence in learning incident that is learners' enjoyment or anger while they are learning. Emotion is also attributed to learner's experience in his/her learning while learning situation is related to important circumstances from learner itself. Motives in learners are essential triggers to predict success on learning process

\section{Method}

The design of this research was institutional case study. The study investigated and described the mental states of participants while they were implementing 5Rs Self Reflective Strategies in learning L2 reading texts. The study applied qualitative data in the form of participants' interview results and interpreting results on the participants' learning logs. The quantitative data was the results of the participants' questionnaires.

The investigation and analysis on existed cases carried out from participants' learning logs. To sustain deeply analysis, questionnaires and interviews done online were distributed and collected from the participants.

\section{Participants of the Study}

The participants of this study were selected from students of a local university from East Java Province. The numbers of the participants were 10 students of English department.

They were 8 female students and 2 male students whose age range from 21 years old to 23 years old. They were students of semester 7 and they were preparing to enroll TOEFL class preparation.

\section{Instrument and Procedures}

Learning logs sheets were distributed via WhatsApps group to each participant. There were three learning $\operatorname{logs}$ sheet for distribution to each learner as participants in each session of Reading class meeting. The documentation of EFL learners' learning logs were used to explore more 
about learners' learning experiences.

Questionnaires and interview were organized after learning logs were collected and grouped refer to each code. Both questionnaires and interview were done online. Questionnaires were distributed via WhatsApps application, meanwhile interview were done via Google meeting and Zoom application.

\section{Data Analysis}

The learning logs distributed were classified and next, grouped by codes into two categories: (a) the difficulties/problems that learners encountered while they were learning reading subject and (b) the emotional states that EFL learners encountered in solving the problems.

The interview done via online were recorded and interpreted in making evaluation about the use of learning logs in learning L2 reading texts. The findings on students' application on learning $\log$ s from interview results were analyzed and interpreted with the focuses on the difficulties in Reading section.

The questionnaires were distributed via WhatsApps and analyzed to differ the mental states as positive emotion and negative emotion while learners implemented 5Rs Self Reflective Strategies. The questionnaires applied Likert Scales from 1-4.

\section{Findings and Discussion}

From the questionnaires, the findings were analyzed as follows:

Findings were reported that participants used self reflective strategies in learning reading. The numbers of the percentage was $88.1 \%$. The use of self reflective strategies gained from learning $\log$, it was interpreted that most learners drawn in negative emotion at first time they applied it. The negative emotions were interpreted in this study including feeling of laziness to accomplish learning logs provided and ignorance on the use of learning logs. From the second and the third learning logs, it was reported that learners as participants felt more contented at applying their learning logs. Most of participants were secure about the use of learning logs. Feeling secure was interpreted as positive emotion because it would trigger the participants' learning motivation. Interview results to explore the findings were collected and interpreted that most participants felt negative on the use of learning logs at the first time since they perceived their learning logs as assessment sheets for teacher instead of for themselves.

The second findings of application of self reflection on the individual assessment from the participants reported were $81.1 \%$. The interview result exposed that some learners who not submitted learning logs continually affected with their impatience in practicing the steps of self reflective strategies. Some students were reported that they were less self initiated to set their learning goals because of lack of time management. Some students who felt impatient and less initiated they were interpreted from their learning $\operatorname{logs}$ and the frequency of their learning $\log$ submits. Those feelings were interpreted as negative emotion. Most students felt positive on the use of their learning logs. They were reported constantly submit their learning logs and gradually 
they wrote their learning logs to become more completely as the given instructions on learning $\log$ sheets.

The third findings of participants' understanding on Self Reflective strategies were reported in the number of $83.8 \%$. Some learning logs' interpretation showed that some students wrote in very short sentences to accomplish their learning logs that it was result from their lack of skills in practicing self reflective strategies and negative emotions. From the interview result, the findings showed that small numbers of students not accomplish all the given tasks with several reasons for examples time ignorance and difficulties to answer. Meanwhile, most students who felt positive on the use of their learning logs, they would record their learning problems and concern of finding the solution of their learning problems step by step.

The fourth findings reported that understanding of participants in using reading techniques reported were $91.3 \%$. The interview results were reported that fingering techniques on each paragraph while reading applied by most participants. The willingness of the students in using reading techniques was interpreted as positive emotion. It would trigger their motivation on learning L2 texts and to support their reading comprehension on L2 texts provided.

\section{Conclusion}

The study presents the effectiveness of learning logs use in capturing learners' mental states while they are practicing learning strategies as self reflective strategies. The use of learning logs should be applied adaptively step by step. It will make the learners gradually learn that the use of their learning logs can give them some information on their learning process. Learning logs will record learners' learning problem and their mental states during learning process. By reading their learning logs, learners will be taught to make self reflection on their learning process. As the result, learners will positively aware to set up their individual learning goal. Exploration on interview and questionnaires can enrich the data to excavate the emotions involved in learning process from learners.

\section{References:}

Bain, J.D., Ballantyne, \& Lester, N.C. 2002. Reflecting on practice: Student teachers' perspectives. Flaxton: Post Pressed.

Boutet, Isabelle et al. 2017. Evaluating the Implementation and Effectiveness of Reflective Writing. The Canadian Journal for the Scholarship of Teaching and Learning, volume 8, Issue 1, Article 8, Scholarship Western.

Braun, Sandra and Thomas, Stephen. 2013. Student Perceptions of the Use of Learning Logs to Teach Public Writing. Procedia Social and Behavioral Science Science Direct Journal. Elsivier. DOI 10.1016/j.sbspro.2013.10.063

Brown, Douglas, H. 2009. Language Assessment: Principles and Classroom Practices. Long Mann Publisher, ISBN 0-13-098834-0

Çakmak, Zafer and Akgun, Hagan. 2017. A Theoretical Perspectives on the Case Study Method. Journal of Education and Learning, Vol.7, No, 1, 2018.Canadian Center of Education and Science. http://doi.org/10.5539/jel.v7n1p96 
Ching, Chin Poi. 2014. Linking Theory to Practice: A Case Based Approach in Teacher Education. Procedia Science Direct Journal. Elsivier. DOI 10.1016/j.sbspro.2014.01.1425

Colomer, Jordi. Et al. 2013. Reflective Learning in Higher Education: A Comparative Analysis. Proceedia-Social and Behavioral Sciences 93(2013) 364-370. Elsevier Ltd.

Eisenhardt, Kathleen M. Building Theory from Case Study Research. 1989. Academy of Management Review JSTOR. https://about.jstor.org/terms

Fiesner, Tim and Hart, Mike. 2005. Learning Logs: Assessment or Research Method. The Electronic Journal of Business Research Methodology Volume 3 Issue 2 (117-122). www.ejbrm.com

Hamra, Arifuddin and Syatriana, Eny. 2010. Developing A Model Of Teaching Reading Comprehension For EFL Students. TEFLIN Journal, Volume 21, Number 1, February 2010.

Hascher, Tina. 2009. Learning and Emotion: Perspectives for Theory and Research. European Education Journal, Volume 9 Number 1 2010. www.wwwords.eu/EERJ

Helyer, Ruth. 2015. Learning Through Reflection: the Critical Role of Reflection in Work Based Learning (WBL). Journal of Work Applied Management, Vol. 7. Nol (2015)15-17. Emerald Group Publishing, Ltd. DOI 10.1108/JW AM-10-2015-003

Karner, Tobias and Kogler, Kristina. 2016. Emotional States during Learning Situations and Student's Self Regulation: Process Oriented Analysis of Person Situation Interaction in the Vocational Classroom. DOI 101.1186/s40461-016-0038-8

Kolb, Alice and Kolb, David A. 2013. The Kolb Learning Style Inventory-Version. 4.0. www.learningfromexperience.com

Leary, Mark R. Motivational and Emotional Aspects of The Self. The Annual Review of Psychology. DOI 10.1146/annurev.psych.58.110405.085658

Phan, P.Huy et.al. 2019. Predicting and Enhancing Students' Positive Emotions: An Empirical Study from Taiwanese Sociocultural Context. Heliyon Journal. Elsivier. https:// doi.org/10.1016/j.heliyon.2019.e02550.

Ramsey, Caroline. 2006. Introducing Reflective Learning. Palm Callow, S\&P Enterprises Ltd. United Kingdom. ISBN 978-0-7492-2406-6-1.1

Rowe, Frances and Rafferty, Jennifer A. 2013. Instructional Design Interventions for Supporting Self-Regulated Learning: Enhancing Academic Outcomes in Postsecondary E-learning Environments. MERLOT Journal of Online Learning and Teaching, Vol.9, No.4, December 2013.

Schmidt, G.Henk and Lew, D.N. Magdalena. 2011. Self Reflection and Academic Performance: Is There A Relationship. Adv in Health Sci Educ 16:529-545. DOI 10.1007/s10459-011-9298$\mathrm{Z}$

Veine, Sven. Et al. 2019 Reflection as a Core Student Learning Activity in Higher EducationInsights from Nearly Two Decades of Academic Development. International Journal for Academic Development. Routledge Taylor \& Francis Group. https://doi.org/10.1080/1360144X2019.1659797

Zainal, Zaidah. 2007. Case Study as Research Method. Jurnal Kemanusiaan bil. 9, Juni 2007. 